\title{
THE STATE OF THE CRAFT ACTIVITY ON THE TERRITORY OF MORDOVIA (AT THE PRESENT STAGE)
}

(C) 2019

Kandrina Elena Vladimirovna, postgraduate student of Ethnography and Ethnology Department Humanities Research Institute (Saransk, Russian Federation)

\begin{abstract}
In the following paper the author analyzes the state, prospects and problematic aspects of folk arts and crafts existence in the Republic of Mordovia on the examples of the most significant traditional places of their existence. The author uses her own field data analysis as well as archival documents and researchers' materials. The author analyzes transformation of the understanding of the essence and structure of fishing activity in the framework of various historical stages. The place, role, features of folk arts and crafts development in the conditions of an innovative market economy are determined. The main forms of arts and crafts activities for income generation, in which crafts continue to exist are considered. At the present stage, such forms are developed in family contracts, dynasties of craftsmen, among self-employed persons, craftsmen engaged in some kind of applied arts and crafts besides their professional activities. Attention is paid to the production of souvenirs with national symbols as a special type of products in the structure of folk crafts. The paper reflects the main factors which have an effect on the state of various kinds of folk arts and crafts. The fundamental principles that allow to increase the effectiveness of measures aimed at reviving, preserving and developing various types of traditional folk arts and crafts on the territory of Mordovia are formulated.

Keywords: handicrafts; wallow; traditional embroidery; knitting; clay crafting; Mordovia; national artistic trades; traditional national dress; wood carving; crafts; wickerwork; trade; souvenirs; weaving; traditional place of trade existence; economic activity; center of national culture.
\end{abstract}

УДК 9.93/94

DOI 10.24411/2309-4370-2019-12230

Статья поступила в редакцию 04.02.2019

\section{ПРАВОВОЕ ГОСУДАРСТВО И «ГОСУДАРСТВО ПРАВДЫ» В РАБОТАХ М.В. ШАХМАТОВА}

(C) 2019

Быстрюков Владимир Юрьевич, кандидат исторических наук,

доцент кафедры всеобщей истории, права и методики обучения

Самарский государственный социально-педагогический университет (2. Самара, Российская Федераџия)

Аннотация. В начале 1920-х х гг. в русской эмиграции возникло евразийское движение. Его представители пытались объяснить причины русской революции, по-новому оценив исторический путь развития страны и ее культурные особенности. В первой половине 1920-х гг. движение громко заявило о себе и быстро набирало популярность в среде русской интеллигенции. Его лидеры стали привлекать к публикации в евразийских изданиях новых авторов, среди которых оказался выпускник юридического факультета Петербургского университета Мстислав Вячеславович Шахматов. В евразийских изданиях он опубликовал только две статьи. Однако его роль и значение в евразийском движении в современной историографии оцениваются кардинально различно: от причисления к основателям евразийства до отрицания какой-либо значимой роли в его истории. В своих работах, опубликованных в Евразийских Временниках, М.В. Шахматов рассматривал особенности идеально-государственной доктрины древнерусских княжеств и Московского царства на основе летописей и других произведений древнерусской письменности. М.В. Шахматов считал, что право по содержанию сверхсознательно и вытекает из религиозных предпосылок, из правды Божией. Эти идеалы древнерусские люди распространяли на область государственно-правовых явлений. По его мнению, государство ставило себе три главные задачи: блюстительство православия, водворение правды на земле и защиту лишь в общих чертах физического существования народа. «Идея «подвигоположничества» верховной власти из ранней истории христианства пришла в Византию и особую остроту приобрела на Руси. Своего полного выражения «идеально-государственная» доктрина подвига власти достигла в XVI в. М.В. Шахматов отмечал, что политическая реальность жизни древнерусских княжеств и вечевых городов сильно отличалась от идеалов, заложенных в летописях и других произведениях древнерусской письменности. Однако идеал «государства правды» сохранился в трудах славянофилов, Ф.М. Достоевского, П.И. Новгородцева, а также его отдельных проявлениях в практике Российской империи.

Ключевые слова: Русская эмиграция; евразийское движение; М.В. Шахматов; П.Н. Савицкий; Н.С. Трубецкой; Н.Н. Алексеев; Россия-Евразия; «Евразийский временник»; «государство правды»; закон; естественное право; правовое государство; подвиг верховной власти; православие.

Евразийское движение, возникшее в начале 1920х гг. в эмиграции, привлекло в свои ряды достаточно большое количество русских интеллектуалов, представителей различных отраслей знания. Для многих из них участие в движении (в основном заключавшееся в публикации текстов в евразийских изданиях и участии в публичных дискуссиях и диспутах) было только определенным этапом в жизни и творчестве. Можно назвать лишь несколько человек, чья дея- тельность в 1920-30-ее гг., то есть во время существования движения, было связано с евразийством. Ключевой фигурой являлся П.Н. Савицкий, стоявший у его истоков, возглавивший его после «кламарского раскола» и реанимировавший движение в 1930-е гг. В 1920-е гг. идейным лидером считался князь Н.С. Трубецкой, чья брошюра «Европа и человечество» считается первым евразийским текстом [1]. После скандала с Трестом и «кламарского раско- 
ла», Н.С. Трубецкой разочаровался в евразийстве, о чем он с горечью писал П.Н. Савицкому [2], однако в 1930-е гг. в евразийских изданиях было опубликовано несколько его статей, в том числе «Мысли об автаркии» [3], «О расизме» [4], «Упадок творчества» [5] и др. Не менее значима фигура третьего основателя евразийства - П.П. Сувчинского, возглавлявшего «кламарскую группу». После окончания ее деятельности он фактически прекратил участие в евразийстве, сосредоточившись на культурной работе [6]. Четвертый основатель движения - Г.В. Флоровский - отошел от него еще в 1923 г.

К евразийцам «второго порядка» можно отнести Г.В. Вернадского, Н.Н. Алексеева и Л.П. Карсавина. Они внесли существенный вклад в развитие идей евразийства. Н.Н. Алексеев стал ведущим теоретиком права движения, Л.П. Карсавин занял свободную после ухода Г.В. Флоровского нишу главного специалиста в области философии и религии, Г.В. Вернадский, уехавший в 1927 г. в США, использовал идеи евразийства в своих исторических работах [7]. Однако евразийские издания насчитывали гораздо больше авторов. В современных историографических указателях количество фамилии (помимо уже названных выше) превышает два десятка человек [8]. Соответственно встают несколько вопросов: можно ли отнести этих авторов к движению, какова их роль в евразийстве, и самый главный - какое значение для евразийской идеологии имели их взгляды, можно ли их безусловно отнести к «евразийским»? [9]. Попробуем ответить на них на примере участия в движении историка и юриста, профессора Русского юридического факультета в Праге Мстислава Вячеславовича Шахматова (1888-1943).

В современной историографии участие М.В. Шахматова в истории движения и его работы рассматриваются достаточно редко, почти всегда в увязке с идеями В.Н. Ильина и Н.Н. Алексеева. А.А. Суслов причисляет М.В. Шахматова, наряду с П.Н. Савицким, Н.С. Трубецким, П.П. Сувчинским, Г.В. Вернадским, Л.П. Карсавиным и Н.Н. Алексеевым, к основателям и ведущим идеологам движения [10]. Совместно с последним автором М.В. Шахматов являлся автором «евразийской концепции «государства правды», и хотя он достаточно рано отошел от движения, две его статьи, опубликованные в III и IV Евразийских временниках сыграли заметную роль в формировании евразийской историософии [11]. Ярким и интересным евразийским правоведом, активным членом евразийского движения называет М.В. Шахматова А.А. Васильев [12]. Е.А. Куликов и И.И. Бирюков указывают, что возрожденная евразийцами Н.Н. Алексеевым и М.В. Шахматовым концепция «государства правды», берущая начало в трудах заволжских старцев (нестяжателей) - Нила Сорского, Максима Грека, Вассиана Патрикеева, - органично вписалась в общую тенденцию пробуждения традиционализма в мировой мысли XX века [13].

В отличие от приведенных авторов Б.В. Назмутдинов не считает М.В. Шахматова евразийцем, а только «спецом», которого не допускали до участия в движении, а его работы не могли помочь евразийству в обосновании политико-правовых проектов по устройству государственного строя будущей России. Б.В. Назмутдинов отмечает, что М.В. Шахматов сдержанно оценивал роль ордынского влияния, считая, что оно лишь преобразовало древнерусские гос- ударственные идеалы, близкие, прежде всего, христианским идеалам подвига и жертвенности. «Подобные идеалы в том числе обусловлены воззрениями Платона: исследователь обнаружил в древнерусских религиозных и светских текстах многочисленные извлечения из трудов греческого философа. Связь подобных высказываний с постулатами евразийства неочевидна, потому Шахматова и нельзя назвать евразийцем» [14].

Е.Н. Дербин оценивает появление М.В. Шахматова с двумя статьями в «Евразийских временниках» как во многом случайное и считавшееся обеими сторонами (основоположниками евразийства и им самим) ошибочным. В самом движении он никогда не участвовал и евразийцев публично не поддерживал [15]. М.В. Шахматов воспользовался предложением П.Н. Савицкого или Г.В. Флоровского, которые в то время искали «спецов» для раскрытия специальных тем исследования на страницах евразийских изданий. Концепция «государства правды» была гораздо ближе к славянофильству, нежели к евразийству, единственное, что роднило с последним М.В. Шахматова, это представление о самобытности исторического пути России и его резком отличии от Запада. В целом концепцию М.В. Шахматова и евразийские взгляды, по мнению Е.Н. Дербина, необходимо разделять [16].

Таким образом, оценки места М.В. Шахматова в истории евразийского движения различаются весьма существенно. Обратимся к мнению представителей евразийства. Рассуждая о сложностях взаимоотношениях с Г.В. Флоровским и о публикации «Евразийских Временников», Н.С Трубецкой в письме к П.П. Сувчинскому в конце декабря 1923 г., называл М.В. Шахматова «охотно идущим к нам спецом», которому можно «спорадически заказывать статьи, не подпуская к редактированию». Соглашаясь с тем же Г.В. Флоровским, Н.С. Трубецкой писал, что у М.В. Шахматова дурной вкус вкупе с излишним лиризмом и отсутствием предметности в текстах [17]. В том же письме Н.С. Трубецкой указывал тематику статьи - «Татарщина как религиозная эпоха», однако в итоге в работе «Государство правды» акценты оказались существенно смещены. Рассматривая развитие евразийской историографии в 1920-е гг. П.Н. Савицкий указывал, что III Евразийский временник был значительно слабее предыдущих, а в IV Временнике статья «Государство правды» посвящена истории государственных идеалов в Древней Руси [18]. В остальных библиографических работах П.Н. Савицкого места М.В. Шахматову не нашлось.

Сам М.В. Шахматов в письме в редакцию «Возрождения» в 1925 г. писал, что опубликовал две статьи нейтрального научно-философского содержания в евразийских изданиях, несмотря на то, что евразийцем никогда не был и по ряду вопросов с ними не соглашался. Несмотря на положительное отношение к самобытности русской культуры, в остальном он предпочел отмежеваться от позиции евразийцев, особенно в отношении истории страны в XVIIIXIX вв. и революции 1917 г. Использование термина «Евразия» М.В. Шахматов называл «уничтожением достижений всей русской истории» [19].

Таким образом, следует согласиться с точкой зрения Е.Н. Дербина и Б.В. Назмутдинова и признать факт случайности нахождения М.В. Шахматова в евразийских рядах. Он считался приглашенным «спецом», на большее сам не претендовал и после двух 
лет сотрудничества публично отмежевался от евразийства.

Однако признание этого факта не снимает вопроса о месте идей М.В. Шахматова, выдвинутых им в статьях, опубликованных в Евразийских временниках, в идеологии движения в целом. С учетом III Евразийского временника, в первых коллективных изданиях евразийцев, помимо четырех основателей движения, также публиковались А.В. Карташев, П.М. Бицилли., Н.С. Арсеньев, Я.Д. Садовский и В.Н. Ильин, причем к составу движения можно отнести только последних двух авторов. Можно сделать вывод, что евразийцы активно пытались привлечь в свои ряды новые лица, предоставляя место на страницах евразийских изданий. В чем-то судьба М.В. Шахматова созвучна судьбе В.Н. Ильина: оба были привлечены в 1922-1923 гг. к участию в изданиях движения, и оба же публично отмежевались от евразийства с разницей в девять лет: М.В. Шахматов сделал это в 1925 г., В.Н. Ильин - в 1934 г. (и оба сделали это на страницах газеты «Возрождение»). В евразийских изданиях В.Н. Ильин опубликовал более десятка работ и идеи высказанные в них, в современной историографии в целом относятся к евразийским. Но факт отнесения В.Н. Ильина к евразийцам строится не только на количестве публикаций, а на их смысловом содержании.

Рассмотрим работы М.В. Шахматова: «Подвиг власти» [20] и «Государство правды» [21] и соотнесем их с ключевыми евразийскими постулатами. В первой половине 1920-х к таковым можно было отнести радикальную критику универсалистской европейской культуры и объявление России особой цивилизацией, географическим, этнографическим и культурным миром [17].

М.В. Шахматов делал упор на анализе «истории идей», объединяя «историческую правду и идеализирующие домыслы» [20] и пытался найти в произведениях древнерусской письменности, в первую очередь, в летописях, идейное государственно-правовое содержание, вытекавшее из синтеза «конкретного национально-государственного строя и идеала и идеалами религиозными» [21]. Первоисточниками в этом плане были общие заповеди христианства. М.В. Шахматов отмечал «стремление Древней Руси символически и обрядово изобразить сущность православия в связи с Вечной Правдой, которая была идеалом строительства государства и власти. По его мнению, понятие, аналогичное термину «естественное право», входило в состав более обширных терминов «закон» и «правда». Первое из них означало религиозный, естественный и государственный закон и возводилось к христианскому учению. Понятие «правда» было аналогично понятию «право», обозначая и нормы справедливости и нормы естественного права, право в объективном и субъективном смыслах, право положительное и идеальное. Право по содержанию вытекает из религиозных предпосылок и сливается с правом по форме в «государстве правды».

Это приводило М.В. Шахматова к мысли о необходимости построения наряду с правовым государством второго вида государства, а именно - «государства правды», представлявшего иной вид мировоззрения. «Правовое государство» - правление серых будничных людей, «государство правды» правление героя, подвижника, великомученика» [20]. Правовое государство оказывается слишком узким для широких просторов Руси, так как русская культура, включавшая в себя европейскую, ею не исчерпывалась.

Только в «государстве правды» право по форме совпадает с правом по содержанию и только там существует истинное право. Наиболее важной идеей в идеале «государства правды» является подчинение государства началу вечности. Это приводит к следующим историческим последствиям:

1. Невозможность установить «государство правды» одномоментно, в результате какого-либо исторического события. Осуществления идеала необходимо добиваться долгое время тяжкими трудами и подвижничеством.

2. Вопрос юридического строения государства отступает перед вопросом преемства благодати от Бога.

3. Целью «государства правды» является религиозное спасение, и только потом - земное.

4. Власть в «государстве правды» исходит от Бога, следовательно форма правления не устанавливается, а заслуживается.

5. «Государство правды» основывается на преданности народа и правителя государственно-религиозному идеалу [21].

«Государство правды» устанавливается не через введение конституции, а через нравственные и религиозные цели и нравственную организацию. «Реально это выражалось в первенстве блюстительства православия над остальными государственными целями в священном звании царя, являющегося не только правителем, но и пастырем, и в стремлении подчинить Правду государственную Правде Вечной. А Вечная Правда требовала ото всех народов, партий и классов Российского Царствия в единый союз любви вокруг «превысочайшего» престола богоутвержденного царя» [21]. Дробление большого государства вело к войнам между его частями. Самодержавие совпало с «государством правды», поскольку отрицало возможность междукняжеских усобиц. Межгосударственные отношения и отношения между властью и народом должны быть построены не только на силе и на формальном праве, но и на принципах любви и правды.

В летописях отражено стремление к государственной правде начиная со времени призвания варягов. Князья, соответствующие этому идеалу, такие как Ярослав Мудрый и Владимир Мономах, пользовались огромным авторитетом, их правление считалось осуществлением политического идеала. Проповедь «правды» является квинтэссенцией русских летописей и других произведений древнерусской письменности, а ее высшим осуществлением является христианская любовь. Самоопределение национальностей, как и классовая борьба противоречили принципу христианской любви. Осуществление правды в общественных отношениях является залогом существования государства. В летописях XI-XII вв. М.В. Шахматов видел стремление «сочетать идеал правды с существовавшим тогда государственным строем» [21]. Испытания, которым русские княжества и земли подверглись в XIII-XIV вв. стали признаком невозможности соединить Правду с княжеским «многодержавием» и вечевым строем.

Совершение подвига власти становится требованием идеального русского права, именуемого правдой, а его целью - общественное благо, которое мыслилось как духовное спасение народа, а уже потом как обеспечение материального благополучия. 
М.В. Шахматов выделял два вида подвигов: «нравственно и юридически безразличные подвиги былинных богатырей и подвиги во имя высоких убеждений, ближнего и отечества, целью которых являлось служение праву, правде и справедливости.

Установление ордынского ига является рубежом в историческом процессе, отделившим «богатырские подвиги русских князей от подвигов князей-страдальцев». «В этом отношении роковое монгольское нашествие оказывает облагораживающее влияние на построение русских понятий о государственной власти» [20]. После татарского нашествия усиливается дифференциация концепта «правда», противопоставившая два государственных порядка - русско-христианский и ордынский, идеально-добрый и злой. М.В. Шахматов указывал на огромное значение Твери в развитии русской государственности, давшей семью «князей-великомучеников». Постепенно вырабатывалась идеология, подразумевавшая мученическую кончину за русскую землю, воспринятая московскими князьями. Среди хитросплетений «realpolitik» Москвы два события были овеяны ореолом «подвига»: Куликовская битва, заложившая основы великорусской государственности и взятие Казани, которое вывело Россию на путь великодержавия. Дмитрий Донской стал князем-подвигоположником, после которого идеал правителя становится все более возвышенным. Своего апогея этот образ достиг в XVI в., когда Россия стала в большей степени «идеалоправством», нежели «теократической монархией».

Освобождение от ордынского ига и объединение Руси вызвали национальный и религиозно-политический подъем в обществе, отразившийся в письменных источниках. В XV-XVII вв. направленность летописей и других произведений письменности меняется, там постепенно утверждается мысль о том, что «государство правды» нашло свое воплощение в Московском княжестве.

Законченное выражение доктрина получила в Степенной книге, связавшей могущество страны с верностью православию и святости многих князей. Столетие, включающее в себя правление Ивана III и доопричный период правления Ивана IV стало временем высшего развития идеала «государства правды». «В логическом составе Московского идеала «государства правды» была два важных момента: вопервых подчинение всего русского народа единодержавной воле Московского Государя, во-вторых, отказ последнего от собственной воли и подчинение ее Воле Божией» [21]. В социальной жизни Московского государства множество мелких групп-«чинов», отсутствие крупных сословий или классов затрудняло нарушение социального мира.

Опричнина и поражение в Ливонской войне поколебали идеал «государство правды», однако он все равно помог преодолеть Смуту и восстановить сильную государственную власть. В последующем идеал «государства правды» постепенно заменялся другими идеалами: регулярного государства, просвещенного абсолютизма, правового государства. Но его «осколки» проявляли себя «в некоторых идейных предпосылках нашего законодательства, в идеологии старообрядчества, в некоторых направлениях нашей литературы, в представлениях народной массы» [21].

Генезис естественного права на Руси представлял собой иную логику развития, отличавшуюся от Западной Европы, где гражданские права и свободы противопоставлялись правам абсолютного монарха. «Правда» как система русского идеального права построена не на противопоставлении правителя и народа, а на их взаимной христианской любви [20]. «Государство правды» представляет систему идей, отличную от аналогичных систем, таких как восточная теократия и западноевропейское средневековое государство. Москва не смогла осуществить его до конца, однако он не потерял своего значения и возможности быть фундаментом для строительства идеалов в другие времена [21].

М.В. Шахматов отмечал кризис правового сознания современной Европы, вытекающего из отделения права от нравственности и построения государства исключительно на правовых основаниях. «Современная Европа отошла от идеала «государства правды», некоторые его элементы сохранились разве лишь в Англии, где не совсем еще отделены религия, право и нравственность» [21]. Кризис современного правосознания был порожден крайностями излишней юридизации общественной и государственной жизни.

Таким образом, несмотря на то, что в текстах М.В. Шахматова концепт «Евразия» не упоминался ни разу, в них были некоторые ассоциации с идеями евразийства. Противопоставление России и Европы в статьях было проведено достаточно сильно и если правовые конструкты выглядели несколько умозрительно, то религиозно-правовые границы были обозначены очень четко и влияние Европы в целом могло оцениваться только негативно. Религиозный пафос статей вполне соответствовал общему умонастроению евразийцев. Представители движения были людьми религиозными, и достаточно часто обращались к таким темам в своих текстах. Религия для них не была вопросом конъюнктуры [22].

Характерна роль монгольского ига как катализатора процессов построения «государства правды», зависимость от Орды здесь сыграла положительную роль. Общие идеалы «Государства Правды» исходили из Библии, христианства и через Византию попали на Русь. Нечто подобное, в виде двух наследств византийского и монгольского - впоследствии будет описывать Г.В. Вернадский. В целом, идеологическая преемственность с Византией, как другого «евразийского» государства характеризуется в работах П.Н. Савицкого. Положительная характеристика эпохи Московского царства (как противовеса западнической империи Романовых) также вполне укладывались в рамки евразийской концепции.

Ссылаясь на М.В. Шахматова, М. Ларюэль указывает, что «русское государство правды, созданное в период монгольского ига, постепенно исчезало благодаря обмирщению времени Петра и желанию Романовых превратить его в европейское «правовое государство» [23]. Однако сам М.В. Шахматов относил начало этого процесса за полтора столетия до Петра и связывал его со стремлением Ивана Грозного к установлению самодержавной власти.

Наконец, историографическая традиция, упомянутая М.В. Шахматовым в каждой из статей - о том, что многие аспекты летописных политических учений были восприняты из Библии и Византии, после древней Руси они были возрождены в работах славянофилов, Ф.М. Достоевского и П.И. Новгородцева, в целом соответствовала той интеллектуальной генеалогии, которую, например, П.Н. Савицкий выстраивал в работе «Два мира» [24]. 
Таким образом, концепция Государства Правды», выдвигаемая в двух статьях М.В. Шахматова, вполне укладывалась в рамки евразийской концепции, по крайней мере, в те идеологемы, которые существовали в середине 1920-х гг. Однако причиной таких совпадений скорее являлась абстрактность евразийских конструкций, нежели желание М.В. Шахматова во что бы то ни стало подстроиться под идеи евразийцев. В этом плане характерна статья С.Ю. Гагена, в которой автор основательно рассматривает идеи и взгляды М.В. Шахматова, ссылаясь как на его «евразийские», так и на другие работы, совершенно не упоминая факт его участия в движении [25].

Евразийская концепция в первой половине 1920-х гг. только начала оформляться, а движение - расширяться, увеличивая число сторонников и сочувствующих. Неудивительно, что многие русские интеллектуалы, верившие в особые пути развития России, в условиях эмигрантской действительности прошли через увлечение идеями нового движения.

\section{Список литературы:}

1. Трубецкой Н.С. Европа и человечество. София: Рос.-Болг. книгоизд-во, 1920. VI. 82 с.

2. Казнина О.А. Н.С. Трубецкой и кризис евразийства // Славяноведение. 1995. № 4. С. 89-95.

3. Трубецкой Н.С. Мысли об автаркии // Новая эпоха: Идеократия. Политика. Экономика: обзоры / под ред. В.А. Пейль. Нарва: Изд. евразийцев, 1933. C. $25-26$.

4. Трубецкой Н.С. О расизме // Евразийские тетради. Париж, 1935. Вып. 5. С. 43-54.

5. Трубецкой Н.С. Упадок творчества // Евразийская хроника. Берлин, 1937. Вып. 12. С. 10-16.

6. Вишневецкий И.Г. «Евразийское уклонение» в музыке 1920-1930-х годов: история вопроса, ст. и материалы А. Лурье, П. Сувчинского, И. Стравинского. М.: Новое лит. обозрение, 2005. 511 с.

7. Рыбаков С.В. Историк-евразиец Георгий Вернадский // Вопросы истории. 2006. № 11. С. 157-164.

8. Евразийство в философско-исторической и политической мысли русского зарубежья 1920-1930-х годов. Библиографический указатель / сост.: Л.Г. Филонова. М., 2011. 117 с.

9. Быстрюков В.Ю. В поисках Евразии: общественно-политическая и научная деятельность П.Н. Савицкого в годы эмиграции (1920-1938 гг.). Самара: Самарское кн. изд-во, 2007. 278 с.

10. Суслов А.А. «Государство правды» в трудах М.В. Шахматова и Н.Н. Алексеева // Свободная мысль. 2007. № 7. С. 180-191.

11. Суслов А.А. Русские политические идеалы в евразийской историософии: образ «государства прав- ды» // Вестник РГГУ. Серия: Философия. Социология. Искусствоведение. 2008. № 7. С. 174-185.

12. Васильев А.А. Евразийская концепция государства правды М.В. Шахматова // Евразийство: теоретический потенциал и практические приложения: мат-лы Шестой всерос. науч.-практ. конф. (с междунар. участием) г. Барнаул, 25-26 июня 2012 г.: в 2 тт. Барнаул: ИГ «Си-пресс», 2012. Т. I. С. 78-82.

13. Куликов Е.А., Бирюков И.И. «Государство правды» и правовое государство: сравнительный анализ на основе правовой доктрины евразийства // Право и политика. 2016. № 8. С. 1068-1074.

14. Назмутдинов Б.В. Политико-правовые воззрения евразийцев в российском государствоведении ХХ века: учеб. пособие. М.: НИУ ВШЭ, 2013. 247 с.

15. Дербин Е.Н. Евразийство и М.В. Шахматов (к вопросу о разграничении точек зрения) // Вестник Калмыцкого института гуманитарных исследований PAH. 2016. № 6. С. 146-152.

16. Дербин Е.Н. Концепция верховной власти Древней Руси М.В. Шахматова и евразийство // Древняя Русь: во времени, в личностях, в идеях. 2017. № 7. С. 334-346.

17. Глебов С. Евразийство между империей и модерном. История в документах. М.: Новое издательство, 2010. $632 \mathrm{C}$

18. Евразийская библиография, 1921-1931: путеводитель по евразийской литературе / Степан Лубенский [псевд. П.Н. Савицкого] // Тридцатые годы. Париж: Издание евразийцев, 1931. С. 285-317.

19. Возрождение. 06.06.1925 № 4. С. 1 .

20. Шахматов М.В. Подвиг власти: опыт по истории государственных идеалов в России // Евразийский временник. Кн. III. Берлин: Евраз. книгоизд-во, 1923. С. $55-80$.

21. Шахматов М.В. Государство правды: Опыт по истории государственных идеалов в России // Евразийский временник. Кн. IV. Берлин: Евраз. книгоизд-во, 1925. С. 268-304.

22. Герасимов Ю.К. Религиозная позиция евразийства // Русская литература. 1995. № 1. С. 159-176.

23. Ларюэль М. Идеология русского евразийства, или Мысли о величии империи. М.: Наталис, 2004. $287 \mathrm{c}$.

24. Савицкий П.Н. Два мира // На путях. Утверждение евразийцев. Берлин: Геликон, 1922. Кн. 2. C. $9-26$.

25. Гаген С.Я. Идея «служилого богатства» в трудах М.В. Шахматова // Россия и мир: панорама исторического развития: сб. науч. ст., посв. 70-летию исторического факультета Уральского государственного университета им. А.М. Горького. Екатеринбург, 2008. C. $65-73$.

\section{LEGAL STATE AND «STATE OF THE TRUTH» IN THE WORKS OF M.V. SHAKHMATOV} (C) 2019

Bystryukov Vladimir Yuryevich, candidate of historical sciences, associate professor of World History, Law and Methods of Teaching Department Samara State University of Social Sciences and Education (Samara, Russian Federation)

Abstract. In the early 1920s, the Eurasian movement emerged in the Russian emigration. Its representatives tried to explain the causes of the Russian revolution, re-evaluating the historical path of the country and its cultural characteristics development. In the first half of the 1920s, the movement loudly declared itself and quickly gained popularity among the Russian «intelligentsia». Its leaders began to attract new authors for publication in Eurasian publications, including Mstislav Vyacheslavovich Shakhmatov, a graduate of the law faculty of St. Petersburg University. He published only two articles in Eurasian publications. However, its role and importance in the Eurasian movement in modern historiography is estimated differently: from being ranked among the founders of Eurasianism to denying 
any significant role in its history. M.V. Shakhmatov considered the features of the ideal state doctrine of the old Russian principalities and the Moscow Kingdom based on Chronicles and other works of ancient Russian script in his works published in the Eurasian Periodicals. M.V. Shakhmatov thought that the right to the content was superconscious and followed from religious premises, from the truth of God. Ancient people spread these ideals to the area of state-legal phenomena. In his opinion, the state set three main tasks: the protection of Orthodoxy, the establishment of the truth on earth and protection of the physical existence of the people. The idea of «podvigopolozhnichestvo» of the Supreme power of the early history of Christianity came from Byzantium. M.V. Shakhmatov noted that the political reality of the life of the old Russian principalities and council cities was very different from the ideals laid down in the chronicles and other works of ancient Russian script. However, the ideal of the «state of the truth» is remained in the works of Slavophiles, F.M. Dostoevsky, P.I. Novgorodtsev, and individual manifestations in the practice of the Russian Empire.

Keywords: Russian emigration; Eurasian movement; M.V. Shakhmatov; P.N. Savitsky; N.S. Trubetskoy; N.N. Alekseev; Russia-Eurasia; «Eurasian time»; «state of the truth»; law; natural law; rule of law; feat of Supreme power; Orthodoxy.

УДК 94 (411).08

DOI 10.24411/2309-4370-2019-12231

Статья поступила в редакцию 05.01.2019

\section{АСИММЕТРИЧНЫЕ КОНФЛИКТЫ В БРИТАНСКОЙ ИМПЕРИИ В СОЧИНЕНИЯХ У. ЧЕРЧИЛЛЯ}

\section{(C) 2019}

Голосова Анна Александровна, магистрант кафедры всеобщей истории, права и методики обучения Самарский государственный соииально-педагогический университет (2. Самара, Российская Федераиия)

Аннотация. В данной статье анализируются работы Уинстона Черчилля первой трети ХХ века, посвящённые его участию в асимметричных военных конфликтах на периферии Британской колониальной империи. Это позволяет нам, во-первых, рассмотреть понятие асимметричного конфликта применительно к британской армии на рубеже веков, а также сразу после Первой мировой войны. А, во-вторых, проанализировать методы, формы и способы ведения войны в условиях неравных силовых возможностей, что позволит нам познакомиться с тем образом колониальных окраин, который сформировался у британцев в условиях происходивших конфликтов. В статье прослеживается чёткая хронология в соответствие с работами У. Черчилля: Кубинская война за независимость, восстание пуштунских племён в Малаканде, махдистское восстание в Судане, вторая англо-бурская война, ирландская война за независимость. Уинстон Черчилль лично проходил службу в британской армии, вместе с тем являясь военным корреспондентом, освещавшим военные события с линии фронта. Из цепочки событий выбивается лишь ирландская война за независимость, с одной стороны являясь асимметричным военным конфликтом, она воспринимается У. Черчиллем совсем с других позиций: через призму политического опыта и с высоты своего поста министра колоний. В заключительной части статьи обосновывается вывод о колониальной эпохе как основе формирования теоретической составляющей понятия асимметричного конфликта.

Ключевые слова: асимметричный конфликт; Уинстон Черчилль; британская империя; Великобритания; колониальные конфликты; колонии; Малаканд; Судан; англо-бурская война; независимость Ирландии; ИРА; колониальная эпоха; партизанская война; Дэвид Ллойд-Джордж; локальные вооружённые конфликты; британская армия; ирландский вопрос.

Одной из основных составляющих международных отношений в качестве средства разрешения противоречий между государствами были, есть и будут вооружённые конфликты. На сегодняшний день асимметричные конфликты перестали быть единичным явлением среди вооружённых конфликтов. Ведь сверхдержавы стремятся увеличить технологический разрыв со всем остальными игроками на международной арене, и дисбаланс в военном потенциале стал характерной чертой военных столкновений последних десятилетий.

Поэтому, как и современная система международных отношений, время расцвета колониальной эпохи характеризовалось серьёзным уровнем международной напряжённости. И учитывая специфику существования империй, возникновение локальных вооружённых конфликтов, наносивших урон национальной безопасности государства, было неизбежным. В таких условиях, маловероятным казалось их мирное урегулирование. Но часть таких конфликтов показала, Самарский научный вестник. 2019. Т. 8, № 2 (27) что не всегда возможно победить даже при условии преобладания силовых возможностей [1; 2, с. 67].

Безусловно, идеальные симметрии редко присутствуют на войне. Тем не менее, с каждым десятилетием модели несоответствия кажутся всё более систематическими и структурированными, чем прежде.

Термин «асимметричные конфликты», со времён ввода в научный оборот Э. Маком в середине 1970-х годов, используется при анализе вооружённых конфликтов в условиях неравных военных и экономических ресурсов воюющих сторон [3]. Особое внимание уделяется изучению парадоксального поражения великих держав в «малых войнах», либо рассматриваются конкретно-исторические примеры этого явления, в том числе и современные конфликты - в Ираке, Ливии, Сирии и т.д. [4, с. 25].

Данная статья посвящена восприятию асимметричных конфликтов на колониальных окраинах Британской империи Уинстоном Черчиллем, являвшимся одной из самых влиятельных и противоречивых фигур в истории Британской империи и всего XX века. 